\title{
Subclinical Hyperthyroidism and the Cardiovascular Disease
}

\author{
Author \\ Alessandro P. Delitala
}

Italy

Tel.: + 39/0792/28 184; +39/347/7057 777,

Fax: +39/0792/28 207

aledelitala@tiscali.it

\section{ABSTRACT}

Thyroid hormone excess has complex metabolic effects, particularly on the cardiovascular system. Treatment of these conditions is universally suggested by international guidelines. Subclinical hyperthyroidism, defined by reduced or suppressed TSH levels in the presence of normal free thyroxine and free triiodothyronine values, is common in the general population and progressively increases with aging, being as high as $15.4 \%$ in subjects more than 75 years old and more frequent in subjects with nodular goiter. Subclinical hyperthyroidism is often asymptomatic and the diagnosis is incidentally made during screening exams. However, this form of thyroid disorder has gained attention in the last years for its association with cardiovascular disease, in particular with atrial fibrillation. Less clear are the effects of subclinical hyperthyroidism on blood pressure, stroke, or heart failure. The decision to treat subclinical hyperthyroidism is made on the clinical judge, particularly in elderly patients and/or in the presence of comorbidities.

\section{Introduction}

Hormones and cardiovascular system are strongly associated and disorders of hormonal secretion may lead to increased cardiovascular risk [1,2]. Thyroid hormones exert important actions on the cardiovascular system, as demonstrated by the adverse clinical effects that can occur in states of hyperthyroidism and hypothyroidism. Patients with hyperthyroidism have alterations in cardiovascular function, which is in part due to the hypermetabolism and the need to dissipate the excess of heat produced [3]. Thyroid disorders can impair the cardiovascular risk factors, such as those included in the definition of metabolic syndrome $[4,5]$. Indeed, excess as well as lack of thyroid hormone have been linked to alteration in the cardiovascular hemodynamic [6], modifications of heart rhythm $[7,8]$ and arterial wall structure [9-11]. While the effects of thyroid hormone excess on the cardiovascular risk factors are clear for some of them, others are still debatable [12,13]. Finally, a worst lipid profile has been demonstrated in hypothyroidism [14, 15], while a hyperthyroid state was associated with an accelerated lipid metabolism and increased frequency of hepatic injury $[16,17]$.

Overt thyroid disorders, defined as an alteration of thyrotropin (TSH) with increased free thyroxine (FT4) and/or free triiodothyro- nine (FT3) are clinically evident and an early diagnosis is usually made. Treatment is universally suggested by guidelines for a prompt relief of symptoms and to avoid long-term consequences. Subclinical disorders of thyroid gland, defined as TSH outside the reference range of values and FT3 and FT4 within the normal range, are more subtle diseases and the diagnosis is incidentally made during screening exams. Subclinical hyperthyroidism, defined as low TSH and free hormones within the reference range, has gained attention in the last years for its association with cardiovascular disease (CVD), in particular with atrial fibrillation (AF). Aging is associated with a deterioration of classical cardiovascular risk factors [18] but, albeit subclinical hyperthyroidism is more prevalent in the elderly, the temporality ascertainment between thyroid dysfunction and onset of CVD is not always estimable. Further, there is lack of randomized prospective controlled studies conceived to assess the treatment of the disorder, which, in addition, is limited by a variety of side effects. Treatment of subclinical hyperthyroidism is similar to the therapy of overt hyperthyroidism [19,20], but the indication for the treatment has not been standardized.

Here, we have reviewed the effect of subclinical hyperthyroidism on CVD and mortality. 


\section{Materials and Methods}

We performed on PubMed a literature search for the articles published until March 2017 by using the search terms 'subclinical hyperthyroidism', 'cardiovascular disease', 'atrial fibrillation', 'blood pressure', 'stroke', 'heart failure', 'all-cause mortality'. Titles of interest were further reviewed by abstract.

\section{Epidemiology}

Subclinical hyperthyroidism is common in the general population and its frequency is variable, depending on age, sex, and iodine status. In the National Health and Nutrition Examination Survey, $2.5 \%$ of the population had serum TSH below the lower limit of reference range [21]. In Europe, some population surveys analyzed the prevalence of thyroid disorders with different results, perhaps reflecting different age ranges of cohorts and other environmental factors. In Italy the prevalence of subclinical hyperthyroidism not previously diagnosed was 2.4\% [22], while in Germany Volzke et al. found a prevalence of $1.8 \%$ [23]. Another survey in Italy found an overall prevalence of thyroid functional autonomy (i. e., subnormal TSH concentrations and normal concentration of FT3 and FT4) of $4.6 \%$. Finally, the overall prevalence of subclinical hyperthyroidism was lower in Spain (1.3\%) [24] and higher in Denmark (9.7\%) [25].

The frequency of subclinical hyperthyroidism progressively increases with aging, being as high as $15.4 \%$ in subjects more than 75 years old and was more frequent in subjects with nodular goiter [26]. Further, the prevalence of functional thyroid autonomy is much higher than that reported in iodine-sufficient areas, where this condition is rare. Non-autoimmune hyperthyroidism is usually found in subjects with long-standing nodular goiter and is increased in iodine deficient area due to an increased frequency of toxic nodular goiter [26], and consequently, subclinical hyperthyroidism is more frequent in iodine deficient in comparison compared to an iodine replete area $[24,27,28]$.

\section{Progression to overt hyperthyroidism}

The evolution of subclinical hyperthyroidism is variable. Some subjects may progress to overt hyperthyroidism, or can revert to euthyroidism. In general, subclinical hyperthyroidism tends to be stable over years in subjects with multinodular goiter in area with iodine deficiency. However, the risk of progression to toxic multinodular goiter is higher in area with adequate iodine intake and occurred in $10 \%$ of subjects after 5 years of follow-up [29]. Level of TSH is a strong predictor of progression to overt hyperthyroidism (suppressed TSH, FT3, and FT4 over the upper limit of reference range). After 7 years of follow-up, subjects with mild reduction of TSH (TSH 0.4-0.1) have a low risk to progression (less than $1 \%$ ) [30], while $20 \%$ of patients with decreased TSH level $(0.1 \mathrm{mUI}$ / $\mathrm{ml}$ or lower) progress to overt hyperthyroidism [31]. Subclinical hyperthyroidism may be also transient and may normalize in $25-50 \%$ of subjects particularly in autoimmune-mediated hyperfunction of the gland [32, 33].

Thus, the natural history of subclinical hyperthyroidism is unpredictable but it can be precipitated by iodine overload (drugs or contrast agent for computed tomography), which favors the progression to overt hyperthyroidism.

\section{Thyroid hormone and the cardiovascular system}

Thyroxine (T4) is the most abundant hormone secreted by the thyroid gland and is converted into triiodothyronine (T3), the biologically active compound, by type 1 iodothyronine deiodinases (ID), which is distributed widely and maintains circulating T3 levels. Type 2 ID catalyze the inactivation of FT4 and FT3 while type 3 ID acts like type $1 \mathrm{ID}$, and is expressed in skeletal and cardiac muscles, and in vascular smooth muscle, thus providing local intracellular production of T3 [34].

The effects of thyroid hormones on the cardiovascular system are complex and multiple [35], and include genomic and non-genomic effects. In the heart, once the conversion from T4 to T3 is performed, which usually occurs outside cardiac myocites [34], T3 enters inside the nucleus of the myocites, binds and activates nuclear receptors that mediates changes in gene expression, which encode the production of structural and regulatory proteins. Thus, T3 has a positive chronotropic and inotropic effect on systolic function and further increases the speed of diastolic relaxation [36]. These effects are mediated through the binding of T3 with thyroid hormone receptor (TR). TR is widely expressed and exists in two forms: TR- $\alpha$, encodes by TR- $\alpha$ gene (chromosome 19), and TR- $\beta$, which is derived from TR- $\beta$ gene (chromosome 3 ) [37]. Both TR occurs in different isoforms with a specific tissue expression: TR- $\alpha 1$ is a functional receptor that binds triiodothyronine (T3) and is highly expressed in cardiac and skeletal muscles; TR- $\alpha 2$ is a non-hormone binding receptor acting as negative regulator. Isoforms of TR- $\beta$ are generated by alternative promoter choice: TR- $\beta 1$ is predominately expressed in liver and is involved in cholesterol and bile acid metabolism and TR- $\beta 2$ [15], which is primarily limited to the hypothalamus and pituitary where it plays a key role in negative feedback of thyroid hormone on the thyroid hypothalamic axis [38-40]. The number of $\beta$-adrenergic receptor are also increased in cardiac myocytes and pulse rate frequency are the result of thyroid hormone action on these receptors [3]. Additional actions of thyroid hormone on the heart include adenyl cyclase activity, calcium transport, sodium-potassium ATPase, and cardiac myosin ATPase isoenzymes [41]. In particular, thyroid hormone excess favors the production of $\alpha$-chain, which results in increased ATP to ADP conversion thus enhancing myocardial contractility. $\beta$-Chains have reduced capacity to convert ATP to ADP resulting in weak cardiac contractility. The expression of messenger RNA that encodes these chains is lower in hyperthyroidism whereas messenger RNA that encodes the alpha-chains is high. These differences are mediated, but the different effects of thyroid hormone excess on the expression of the genes are due to heavy chains [41].

The non-genomic effects of the thyroid hormones have a more rapid onset of action and include changes in performance of calcium, sodium and potassium channel at heart level [42]. Moreover, thyroid hormones interact with the sympathetic nervous system by altering responsiveness to sympathetic stimulation probably by modulating adrenergic receptor action and/or density. Pathophysiological consequences of such direct and indirect thyroid hormones effects include increased myocardial contractility and relaxation.

In addition, thyroid hormones exert effects on the vascular system, since they decrease systemic vascular resistance by vasodilation of the peripheral circulation. This effect is possibly mediated by a direct action on vascular smooth muscle cells or through stim- 
ulation of vasodilatory endothelium-derived substances such as nitric oxide. Peripheral vascular resistance is therefore decreased whereas cardiac output is increased due to an increase in heart rate and stroke volume. Another mechanism might be the interaction of thyroid hormone with the sympathetic nervous system.

Many of the clinical manifestations of hyperthyroidism are similar to those of sympathetic system activation. However, plasma and urine concentrations of catecholamines are not increased in patients with hyperthyroidism. Therefore, thyroid hormones may increase sensitivity to catecholamines in heart and other tissues.

\section{Atrial fibrillation}

Atrial fibrillation is a well-known complication of overt hyperthyroidism, and has been found in $2-30 \%$ at the time of diagnosis of overt hyperthyroidism $[43,44]$. Although only a low percentage of subjects with AF has a functional disorder of the thyroid gland [45], European Society of Cardiology suggests to evaluate thyroid function in all patient with a recent diagnosis of AF [46]. Following studies demonstrated that also subclinical hyperthyroidism is a risk factor for AF. In a study on older subjects during the period of 2007 , Sawin at al. showed that $28 \%$ of patients with subclinical hyperthyroidism developed $\mathrm{AF}$ as compared to $11 \%$ of those with normal thyroid function. Further, patients with low TSH concentration have a relative risk three time higher to develop AF in comparison to euthyroid subjects. Although even patients with subclinical hypothyroidism (defined as increased serum TSH value with normal FT4 and FT3) developed AF, their 10-years incidence was comparable to that of euthyroid subjects [47], as shown in $>$ Table 1 . Similar results have been obtained by Auer et al. in a cross sectional study, which analyzed $>23000$ patients aged 45 or older who were referred to a single center [48]. They found an increased prevalence of AF in subjects with overt and subclinical hyperthyroidism (13\% and $14 \%$, respectively) in comparison to euthyroid subjects (2\%). Notably, other authors found that serum FT4 levels was a predictor on AF, as in subclinical hyperthyroidism, as in subjects with normal thyroid function [49]. Similar results have been obtained by Heeringa et al. in a population-based survey in Holland [50]. They analyzed 1426 elderly subjects ( $>65$ years) with normal thyroid function for a median follow-up of 8 years. Subjects in the lowest quartile of $\mathrm{TSH}$ within the reference range have 2 -fold increased risk of AF in comparison to those in the highest quartile. Further, FT4 showed a graded association with $A F$, increasing from the second quartile to the highest quartile of FT4. Increased risk of AF was reported in subjects with suppressed TSH [51] and in those with TSH $<0.1 \mathrm{mUI} / \mathrm{I}$ and underlying cardiac disease [48].

Subclinical hyperthyroidism, both endogenous and exogenous, might predispose to other cardiac arrhythmias, such as atrial premature and ventricular premature beats $[52,53]$, which decreased after reaching euthyroidism [52].

Predictors of paroxysmal AF, such as specific EKG parameter, and their relation with subclinical hyperthyroidism have been investigated in some studies [54-56]. Duration of $P$ wave duration and $P$ wave dispersion were higher in subjects with subclinical hyperthyroidism as compared to healthy euthyroid group. Intriguingly, the etiology of subclinical hyperthyroidism did not modify the association with EKG parameters, suggesting that alteration of hormone levels rather than its cause might be link with cardiac arrhythmias [54].
The effect of exogenous subclinical hyperthyroidism and AF in subjects with thyroid cancer has not yet been extensively studied. Some authors described an increased heart rate frequency, which decreased during withdrawl of thyroxine $[57,58]$ with a higher prevalence of premature atrial beats at ambulatory electrocardiographic monitoring [58].

Despite nearly all studies describe this association, other authors found that mild subclinical hyperthyroidism was not associated with higher prevalence of AF in elderly women [59]. Treatment of subclinical hyperthyroidism was associated with spontaneous conversion to sinus rhythm in $19 \%$ of the patients, which had also a lower frequency of underlying heart disease in comparison to non-converter (77\% vs. $36 \%$ ) [48].

Taken together these data strongly suggest an association between AF and subclinical hyperthyroidism in particular in elderly patients. Indeed, these patients may have a longer duration of subclinical hyperthyroidism, which is often asymptomatic, and often have pre-existing heart disease such as heart failure, angina, and hypertension, which are all independent risks factors for the onset of AF. Another possibility is that hyperthyroidism might shorten the duration of the repolarization phase of the action potential, thus favoring the probability of arrhythmias [60]. The most probable hypothesis is that subclinical hyperthyroidism might trigger the onset of AF in genetically predisposed subjects with other cardiovascular risk factors.

\section{Blood pressure}

Hypertension is the most common cardiovascular risk factor and may affect over than 30-45\% of the population [61], with an increased frequency during aging [18]. The risk of hypertension in overt hyperthyroidism is well documented but the effect of subclinical hyperthyroidism is debatable. In Busselton Thyroid Study, subjects with reduced TSH concentration $(<0.4 \mathrm{mUI} / \mathrm{l})$ had an increased frequency of hypertension and an increased mean systolic blood pressure, although the latter was restricted to subjects with serum TSH concentrations of <0.1 mUI/I [62]. However, the study, as acknowledged by the authors, was limited by the low sample $(n=35)$. A recent study recorded $24-\mathrm{h}$ ambulatory blood pressure monitoring in 44 normotensive subjects with endogenous subclinical hyperthyroidism [63]. The study showed that patients with subclinical hyperthyroidism had a higher nocturnal mean systolic blood pressure, mean diastolic blood pressure, blood pressure load, and mean arterial pressure in comparison to euthyroid state. However, in a German population survey, subclinical hypertension was not associated with hypertension [64]. Although subjects with subclinical hyperthyroidism had increased systolic blood pressure, as compared to euthyroid, adjusting for confounders revealed lower rather than higher adjusted mean values for systolic blood pressure. The same authors followed longitudinally the patients with subclinical hyperthyroidism and they found that it was not associated with changes in blood pressure, pulse pressure, or incident hypertension [65]. The 5-year hypertension incidence was higher in those with subclinical hyperthyroidism as compared to those with TSH within the reference range in the univariate analysis (31\% vs. $19 \%$ ). Logistic regression adjusted for cardiovascular confounders revealed that both groups had similar risk of hypertension. Further, two recent case-control studies, aimed to investigate the associa- 
- Table 1 Studies that analyzed prevalence and incidence of atrial fibrillation and stroke in subjects with subclinical hyperthyroidism.

\begin{tabular}{|c|c|c|c|c|c|}
\hline Study & $\mathbf{n}$ & Age & Female, n (\%) & Events, n (\%) & Follow-up \\
\hline \multicolumn{6}{|l|}{ Atrial fibrillation } \\
\hline Selmer C [90] & 6276 & $60.6 \pm 19.4$ & $4784(76.2 \%)$ & 435 (6.9\%) ศा & 5.5 years \\
\hline \multirow[t]{2}{*}{ Cappola AR [71] } & 47 & $73.9 \pm 6.8$ & 32 (68.1\%) & $4(8.5 \%)^{\pi}$ & \\
\hline & 43 & & & $22(51.2 \%)^{\pi \top \pi}$ & 13 years \\
\hline Auer JA [48] & 613 & $67.9 \pm 9.2$ & $\mathrm{~N} / \mathrm{A}$ & $78(12.7 \%)^{\pi}$ & \\
\hline Rosario PW [59] & 90 & $74(65-82)^{\#}$ & $90(100.0 \%)$ & $4(4.4 \%)^{\pi}$ & \\
\hline Gammage MD [49] & 126 & $N / A$ & $72(57.1 \%)$ & $12(9.5 \%)^{\pi}$ & \\
\hline Goichot B [91] & 86 & $N / A$ & $\mathrm{~N} / \mathrm{A}$ & $10(11.6 \%)^{\pi}$ & \\
\hline Wollenweber FA [76] & 19 & $75(61-80)^{\#}$ & $10(53.0 \%)$ & $7(37.0 \%)^{\pi}$ & \\
\hline \multirow[t]{2}{*}{ Poola R [92] } & 116 & $55(19-98)^{\# \#}$ & $88(75.9 \%)$ & $8(6.9 \%)^{\pi}$ & \\
\hline & 108 & & & $3(2.8 \%)$ )ा & 3.2 years \\
\hline Nanchen D [80] & 71 & $75.3 \pm 3.1$ & $54(76.1 \%)$ & $7(9.9 \%)^{\Upsilon \pi}$ & 3.2 years \\
\hline \multirow[t]{2}{*}{ Schultz M [74] } & 25 & $74.0 \pm 10.0$ & $20(80.0 \%)$ & $1(4.0 \%)^{\pi}$ & \\
\hline & 24 & & & $2(8.3 \%)^{\uparrow \pi}$ & 5.0 years \\
\hline Duarte GC [93] & 26 & $60-85^{\# \# \#}$ & $21(80.8 \%)$ & $3(11.5 \%)^{\pi}$ & \\
\hline Drechsler C [73] & 137 & $66.9 \pm 7.9$ & $74(54.0 \%)$ & $16(12.0 \%)^{\pi}$ & \\
\hline Sawin CT [47] & 248 & $N / A$ & $156(62.9 \%)$ & $36(14.5 \%)^{\top \pi}$ & 10 years \\
\hline Klein Hesselink* [94] & 518 & $48.6 \pm 13.4$ & $387(74.7 \%)$ & $35(6.8 \%)^{\pi \pi}$ & 8.7 years \\
\hline Biondi $B^{*}[58]$ & 20 & $N / A$ & $18(90.0 \%)$ & $1(5.0 \%)^{\pi}$ & \\
\hline \multicolumn{6}{|l|}{ Stroke } \\
\hline Drechsler C [73] & 137 & $66.9 \pm 7.9$ & $74(54.0 \%)$ & $7(5.1 \%)^{\Upsilon \pi}$ & 4.0 years \\
\hline Wollenweber FA [76] & 19 & $75(61-80)^{\#}$ & $10(43.0 \%)$ & $1 \S(5.3 \%)^{\text {โा }}$ & \\
\hline \multirow[t]{2}{*}{ Schultz M [74] } & 25 & $74 \pm 10$ & $20(80.0 \%)$ & $2(8.0 \%)^{\pi}$ & \\
\hline & 23 & $74 \pm 10$ & $20(80.0 \%)$ & $4(17.4 \%)^{\text {ศा }}$ & 5.0 years \\
\hline Selmer C [90] & 6276 & $60.6 \pm 19.4$ & $4784(76.0 \%)$ & $57(0.9 \%)^{\pi}$ & \\
\hline \multirow[t]{2}{*}{ Cappola AR [71] } & 47 & $73.9 \pm 6.8$ & $32(68.1 \%)$ & $2(4.3 \%)^{\pi}$ & \\
\hline & 31 & $\mathrm{~N} / \mathrm{A}$ & $\mathrm{N} / \mathrm{A}$ & $4(12.9 \%)$ ศा & 13 years \\
\hline
\end{tabular}

tion between morphological cardiac parameters [66], and electrocardiogram and echocardiographic characteristics [67], showed that patients with subclinical hyperthyroidism had similar systolic and diastolic blood pressures as euthyroid controls.

Data of the effect of exogenous subclinical hyperthyroidism are rather scanty. Casu et al. showed that patients receiving suppressive l-thyroxine therapy for thyroid cancer had an increased systolic and mean blood pressure, as in ortostatism and in clinostatism [68]. The data, taken together, seems to suggest a small effect of subclinical hyperthyroidism on blood pressure, which can be defined statistically significant but clinically insignificant [63].

\section{Stroke}

Ischemic stroke recognizes two most common causes: thrombotic stroke and embolic stroke. The latter is typical in subjects with AF while thrombotic stroke is associated with atherosclerosis. The risk of stroke in patients with subclinical hyperthyroidism could be related by the increased frequency of $A F$, but also by the alterations of coagulation parameters found in subclinical hyperthyroidism [69]. The frequency of unknown thyroid dysfunctions can be found in $12 \%$ in patients with acute ischemic stroke [70]. However, results of clinical studies and systematic reviews gave conflicting results. In 3233 subjects from Cardiovascular Health Study, the incidence of cerebrovascular event was not increased [71]. These data were confirmed in analysis that included 52674 subjects from 10 cohort studies [72]. Further, acute stroke was not associated with subclinical hyperthyroidism also in specific population highly predisposed to cardiovascular event, such as diabetic hemodialysis patients [73]. Conversely, Schultz et al. found an increased incidence of stroke in subjects with subclinical hyperthyroidism, with a hazard ratio of 3.3, after adjustment of risk factors from stroke [74]. In another cohort study from Denmark, which analyzed over 47 000 subjects consulting their general practitioner, Selmer et al. found that subclinical hyperthyroidism was not associated with stroke [75]. However, when considered the combined end point of major adverse cardiovascular events, which included cardiovascu- 
lar death, non-fatal myocardial infarction, and non-fatal stroke, they found an increased risk in subjects with overt and subclinical hyperthyroidism (IRR 1.16 and IRR 1.09, respectively). Whether subclinical hyperthyroidism might have an impact on the incidence of stroke, its role on functional outcome after a cerebrovascular event is less studied. To the best of our knowledge, there is only one study that addressed this issue. Wollenweber et al. studied a sample of 165 patients admitted to the Hospital for ischemic stroke and found that in 19/165 (11.5\%) subjects with subclinical hyperthyroidism, there was an increased risk of functional disability 3 months after the stroke [76].

The relationship between stroke and subclinical hyperthyroidism is not clear and current evidences do not allow reaching firm conclusions. Whether related, the most probable hypothesis is that subclinical hyperthyroidism increases the frequency stroke due to its association with AF.

\section{Heart failure}

Heart failure (HF) is one the most common cause for hospital admission among subjects 65 years or older. Its prevalence is dramatically increased in the last years and reached epidemic proportions [77]. Several conditions are associated with the progression of HF, such as heart rate, cardiac contractility, and blood hypertension, which can all be worst by functional disorders of the thyroid gland. For this reason and similarly to AF, European guidelines suggest checking thyroid hormones as a possible cause triggering acute $\mathrm{HF}$ [78].

However, most of the studies found an association between low thyroid function and HF. These findings are further supported by the physiology of the action of thyroid hormone [36]. On the other hand, hyperthyroid patients may complain exertional dyspnea and other symptoms of heart failure. The frequency of HF among patients with subclinical hyperthyroidism has a great variability $[79,80]$, because of different diagnostic criteria used for the diagnosis of HF and for the demographic characteristics of the populations studied. Risk of HF was increased in patients with subclinical hyperthyroidism, independently of the degree of reduction of TSH [75]. The authors further hypothesized that HF could explain the association between hyperthyroid states and major adverse cardiovascular events. Similar results have been confirmed in a recent pooled analysis of individual participant data. They found that the risk of HF was increased in subjects with subclinical thyroid dysfunctions (subclinical hypothyroidism and hyperthyroidism) [81]. Interestingly, the hazard ratio increased from 1.31 in those with TSH 0.10-0.44 to 1.94 when TSH $<0.10 \mathrm{mUI} / \mathrm{l}$.

Albeit a recent study found an association between subclinical hyperthyroidism and heart failure [81], Rodondi et al. found that over 12 years, the risk of HF was not increased in subjects with subclinical hyperthyroidism in a cohort of 3044 adults aged 65 or older initially free of HF [82].

It should be noted that this effect might be caused by the alteration linked to subclinical hyperthyroidism (atrial fibrillation, impaired diastolic dysfunction) rather than a direct effect on the heart. Indeed, heart failure seems to be linked to low thyroid function, as demonstrated by the down-regulation of thyroid hormone receptor in the failing heart [36].
It has been postulated that subclinical hyperthyroidism might worst a pre-existing HF. Indeed, in a large cohort of patients aged 70 or older, subclinical hyperthyroidism was associated with an increased rate of admission for HF [80], although other authors do not found this association [83]. The data, collectively, might suggest that subclinical hyperthyroidism could predispose to HF due to its effect on heart rhythm. However, the possible effect of reduction of heart rate to prevent heart failure in patients with subclinical hyperthyroidism should be evaluated in specific clinical trial.

\section{All-cause mortality}

Several prospective cohort studies tried to address the association between subclinical hyperthyroidism and all-cause mortality, but the results are rather conflicting. In 2001 Collet et al. found that a single measurement of low serum TSH was predictive of mortality from all-causes in a population aged 60 or older [84]. Analyzing 1191 individuals over 10-years of follow up, they hypothesized that the excess mortality recorded in subjects with subclinical hyperthyroidism could be linked to the adverse effect on the cardiovascular system.

Meta-analyses gave inconclusive results. Indeed, one meta-analysis included 290 subjects from 7 cohort studies. Authors found a 1.4-fold increase in relative likelihood of death from all causes in subjects with subclinical hyperthyroidism in comparison to euthyroid subjects [85], dependent on age and male gender. The increased risk of death was significant after 2 years from the diagnosis and persisted after 10 years. Similar results have been obtained by Ochs et al., who reviewed over 14400 participants from 10 cohort studies [86]. Conversely, findings of other two meta-analyses showed that subclinical hyperthyroidism was not associated with cardiovascular mortality $[87,88]$.

These data, taken together, might suggest the association between cardiac mortality and subclinical hyperthyroidism might be valuable in particular in older subjects, due to its unfavorable effect on the cardiovascular system. Cardiac function, blood pressure, and heart rate are impaired in patients with low TSH levels. Although the effect of subclinical hyperthyroidism on cardiovascular and all-cause mortality was modest, thyroid dysfunctions are highly prevalent it the general population. However, guidelines suggest against screening of thyroid disorders, even in the older population.

\section{Conclusions}

Subclinical hyperthyroidism is a common clinical problem, in particular in older subjects. However, few randomized controlled studies assessed cardiovascular endpoints after treatment of subclinical hyperthyroidism. Some authors demonstrated a reduction of heart rate, premature atrial and ventricular beats, but the clinical and prospective effects on cardiovascular outcome have not been studied and remain unclear. In addition, most of the studies had a small number of patients, without including a control arm.

The decision to treat subclinical hyperthyroidism is made on the clinical judge, which carefully examined age and comorbidities of the patient. When subclinical hyperthyroidism is diagnosed, experts suggested to repeat the measurement within 4 weeks for 
TSH $<0.1 \mathrm{mUI} / \mathrm{l}$ and after 3 months in subjects with TSH higher than $0.1 \mathrm{mUI} / \mathrm{l}$ and lower than $0.45 \mathrm{mUI} / \mathrm{I}$ [89]. Repeating measures allow discriminating transient (in particular transient thyroiditis) and persistent subclinical hyperthyroidism and avoid overtreatment.

The treatment in older subjects aimed to reduce the incidence of cardiovascular disease, mainly AF. Conversely, there are insufficient data for younger patients, even in case of TSH level $<0.1 \mathrm{mUI} / \mathrm{l}$. The goal of therapy is to normalize TSH level and is based on the etiology of subclinical hyperthyroidism. Appropriate therapy could be radioactive iodine, in case of toxic multinodular goiter, antithyroid drug, in case younger subjects, and surgery, in those who has a concern for cancer.

Experts panel recommended against the routine treatment of subclinical hyperthyroidism in young and asymptomatic subjects with TSH $>0.1 \mathrm{mUI} / \mathrm{l}$. Treatment should be considered in patients aged 65 or older, and in those with symptoms or comorbidities [89]. However, indications for the treatment are not supported by strong evidences because studies analyzing effect of the therapy are rather scanty. In addition, due to the small effect of subclinical hyperthyroidism on CVD and on all-cause mortality, it has been calculated that in order to achieve a power of $80 \%$, sample sizes of the studies would need to be extremely wide in younger age ( $>12000$ patients) and more than 400 when considering only subjects $>70$ years [85].

\section{Conflict of Interest}

The authors declare that they have no conflict of interest.

\section{References}

[1] Prejbisz A, Warchol-Celinska E, Lenders JW, Januszewicz A. Cardiovascular risk in primary hyperaldosteronism. Horm Metab Res 2015; 47: 973-980

[2] Battocchio M, Rebellato A, Grillo A, Dassie F, Maffei P, Bernardi S, Fabris B, Carretta R, Fallo F. Ambulatory arterial stiffness indexes in cushing's syndrome. Horm Metab Res 2017; 49: 214-220

[3] Kahaly G], Dillmann WH. Thyroid hormone action in the heart. Endocr Rev 2005; 26: 704-728

[4] Mehran L, Amouzegar A, Rahimabad PK, Tohidi M, Tahmasebinejad Z, Azizi F. Thyroid function and metabolic syndrome: A population-based thyroid study. Horm Metab Res 2017; 49: 192-200

[5] Delitala AP, Fanciulli G, Pes GM, Maioli M, Delitala G. Thyroid hormones, metabolic syndrome and its components. Endocr Metab Immune Disord Drug Targets 2017; 17: 56-62

[6] Danzi S, Klein I. Thyroid hormone and the cardiovascular system. Med Clin North Am 2012; 96: 257-268

[7] Osman F, Franklyn JA, Holder RL, Sheppard MC, Gammage MD. Cardiovascular manifestations of hyperthyroidism before and after antithyroid therapy: a matched case-control study. J Am Coll Cardiol 2007; 49: 71-81

[8] Kannan L, Kotus-Bart J, Amanullah A. Prevalence of cardiac arrhythmias in hypothyroid and euthyroid patients. Horm Metab Res 2017; 49: 430-433
[9] Delitala AP, Orru M, Filigheddu F, Pilia MG, Delitala G, Ganau A, Saba PS, Decandia F, Scuteri A, Marongiu M, Lakatta EG, Strait J, Cucca F. Serum free thyroxine levels are positively associated with arterial stiffness in the SardiNIA study. Clin Endocrinol (Oxf) 2015; 82: 592-597

[10] Volzke H, Robinson DM, Schminke U, Ludemann J, Rettig R, Felix SB, Kessler C, John U, Meng W. Thyroid function and carotid wall thickness. J Clin Endocrinol Metab 2004; 89: 2145-2149

[11] Wang J, Zheng X, Sun M, Wang Z, Fu Q, Shi Y, Cao M, Zhu Z, Meng C, Mao J, Yang F, Huang X, Xu J, Zhou H, Duan Y, He W, Zhang M, Yang T.Group RS. Low serum free thyroxine concentrations associate with increased arterial stiffness in euthyroid subjects: a population-based cross-sectional study. Endocrine 2015; 50: 465-473

[12] Delitala AP, Filigheddu F, Orru M, AlGhatrif M, Steri M, Pilia MG, Scuteri A, Lobina M, Piras MG, Delitala G, Lakatta EG, Schlessinger D, Cucca F. No evidence of association between subclinical thyroid disorders and common carotid intima medial thickness or atherosclerotic plaque. Nutr Metab Cardiovasc Dis 2015; 25: 1104-1110

[13] Peixoto de Miranda EJ, Bittencourt MS, Goulart AC, Santos IS, Mill JG, Schmidt MI, Lotufo PA, Bensenor IJ. Lack of Association Between Subclinical Hypothyroidism and Carotid-Femoral Pulse Wave Velocity in a Cross-Sectional Analysis of the ELSA-Brasil. Am J Hypertens 2017; 30: $81-87$

[14] Pearce EN. Update in lipid alterations in subclinical hypothyroidism. J Clin Endocrinol Metab 2012; 97: 326-333

[15] Delitala AP, Fanciulli G, Maioli M, Delitala G. Subclinical hypothyroidism, lipid metabolism and cardiovascular disease. Eur J Intern Med 2017; 38: 17-24

[16] Li C, Tan J, Zhang G, Meng Z, Wang R, Li W, Zheng W. Risk factors of hyperthyroidism with hepatic function injury: A 4-year retrospective study. Horm Metab Res 2015; 47: 209-213

[17] Delitala AP, Delitala G, Sioni P, Fanciulli G. Thyroid hormone analogs for the treatment of dyslipidemia: past, present, and future. Curr Med Res Opin 2017; 1-9

[18] Scuteri A, Morrell CH, Orru M, Strait JB, Tarasov KV, Ferreli LA, Loi F, Pilia MG, Delitala A, Spurgeon H, Najjar SS, AIGhatrif M, Lakatta EG. Longitudinal perspective on the conundrum of central arterial stiffness, blood pressure, and aging. Hypertension 2014; 64: 1219-1227

[19] Ross DS, Burch HB, Cooper DS, Greenlee MC, Laurberg P, Maia AL, Rivkees SA, Samuels M, Sosa JA, Stan MN, Walter MA. 2016 American Thyroid Association Guidelines for Diagnosis and Management of Hyperthyroidism and Other Causes of Thyrotoxicosis. Thyroid 2016; 26: $1343-1421$

[20] Neumann S, Place RF, Krieger CC, Gershengorn MC. Future prospects for the treatment of Graves' hyperthyroidism and eye disease. Horm Metab Res 2015; 47: 789-796

[21] Hollowell JG, Staehling NW, Flanders WD, Hannon WH, Gunter EW, Spencer CA, Braverman LE. Serum TSH, T(4), and thyroid antibodies in the United States population (1988 to 1994): National Health and Nutrition Examination Survey (NHANES III). J Clin Endocrinol Metab 2002; 87: 489-499

[22] Delitala AP, Pilia MG, Ferreli L, Loi F, Curreli N, Balaci L, Schlessinger D, Cucca F. Prevalence of unknown thyroid disorders in a Sardinian cohort. Eur J Endocrinol 2014; 171: 143-149

[23] Volzke H, Ludemann J, Robinson DM, Spieker KW, Schwahn C, Kramer $\mathrm{A}$, John $\mathrm{U}$, Meng $\mathrm{W}$. The prevalence of undiagnosed thyroid disorders in a previously iodine-deficient area. Thyroid 2003; 13: 803-810

[24] Lucas A, Julian MT, Canton A, Castell C, Casamitjana R, Martinez-Caceres EM, Granada ML. Undiagnosed thyroid dysfunction, thyroid antibodies, and iodine excretion in a Mediterranean population. Endocrine 2010; 38: 391-396 
[25] Laurberg P, Pedersen KM, Hreidarsson A, Sigfusson N, Iversen E, Knudsen PR. lodine intake and the pattern of thyroid disorders: A comparative epidemiological study of thyroid abnormalities in the elderly in Iceland and in Jutland, Denmark. J Clin Endocrinol Metab 1998; 83: 765-769

[26] Aghini-Lombardi F, Antonangeli L, Martino E, Vitti P, Maccherini D, Leoli F, Rago T, Grasso L, Valeriano R, Balestrieri A, Pinchera A. The spectrum of thyroid disorders in an iodine-deficient community: the Pescopagano survey. J Clin Endocrinol Metab 1999; 84: 561-566

[27] Knudsen N, Bulow I, Laurberg P, Ovesen L, Perrild H, Jorgensen T. Low socio-economic status and familial occurrence of goitre are associated with a high prevalence of goitre. Eur J Epidemiol 2003; 18: 175-181

[28] O'Leary PC, Feddema PH, Michelangeli VP, Leedman PJ, Chew GT, Knuiman M, Kaye J, Walsh JP. Investigations of thyroid hormones and antibodies based on a community health survey: The Busselton thyroid study. Clin Endocrinol (Oxf) 2006; 64: 97-104

[29] Tonacchera M, Pinchera A, Vitti P. Assessment of nodular goitre. Best Pract Res Clin Endocrinol Metab 2010; 24: 51-61

[30] Vadiveloo T, Donnan PT, Cochrane L, Leese GP. The Thyroid Epidemiology, Audit, and Research Study (TEARS): The natural history of endogenous subclinical hyperthyroidism. J Clin Endocrinol Metab 2011; 96: E1-E8

[31] Das G, Ojewuyi TA, Baglioni P, Geen J, Premawardhana LD, Okosieme $\mathrm{OE}$. Serum thyrotrophin at baseline predicts the natural course of subclinical hyperthyroidism. Clin Endocrinol (Oxf) 2012; 77: 146-151

[32] Rosario PW. Natural history of subclinical hyperthyroidism in elderly patients with TSH between 0.1 and $0.4 \mathrm{mIU} / \mathrm{l}$ : A prospective study. Clin Endocrinol (Oxf) 2010; 72: 685-688

[33] Meyerovitch J, Rotman-Pikielny P, Sherf M, Battat E, Levy Y, Surks MI. Serum thyrotropin measurements in the community: Five-year follow-up in a large network of primary care physicians. Arch Intern Med 2007; 167: 1533-1538

[34] Bianco AC, Salvatore D, Gereben B, Berry M], Larsen PR. Biochemistry, cellular and molecular biology, and physiological roles of the iodothyronine selenodeiodinases. Endocr Rev 2002; 23: 38-89

[35] Polikar R, Burger AG, Scherrer U, Nicod P. The thyroid and the heart. Circulation 1993; 87: 1435-1441

[36] Klein I, Ojamaa K. Thyroid hormone and the cardiovascular system. N Engl J Med 2001; 344: 501-509

[37] Baxter JD, Webb P. Thyroid hormone mimetics: Potential applications in atherosclerosis, obesity and type 2 diabetes. Nat Rev Drug Discov 2009; 8: 308-320

[38] Weinberger C, Thompson CC, Ong ES, Lebo R, Gruol D], Evans RM. The c-erb-A gene encodes a thyroid hormone receptor. Nature 1986; 324 : 641-646

[39] Apriletti JW, Ribeiro RC, Wagner RL, Feng W, Webb P, Kushner PJ, West BL, Nilsson S, Scanlan TS, Fletterick RJ, Baxter JD. Molecular and structural biology of thyroid hormone receptors. Clin Exp Pharmacol Physiol Suppl 1998; 25: S2-S11

[40] Zhu X, Cheng SY. New insights into regulation of lipid metabolism by thyroid hormone. Curr Opin Endocrinol Diabetes Obes 2010; 17: 408-413

[41] Kahaly G]. Cardiovascular and atherogenic aspects of subclinical hypothyroidism. Thyroid 2000; 10: 665-679

[42] Schmidt BM, Martin N, Georgens AC, Tillmann HC, Feuring M, Christ $M$, Wehling M. Nongenomic cardiovascular effects of triiodothyronine in euthyroid male volunteers. J Clin Endocrinol Metab 2002; 87: 1681-1686

[43] Sandler G, Wilson GM. The nature and prognosis of heart disease in thyrotoxicosis. A review of 150 patients treated with $131 \mathrm{I}$. Q J Med 1959; 28: 347-369

[44] Nordyke RA, Gilbert FI Jr, Harada AS. Graves' disease. Influence of age on clinical findings. Arch Intern Med 1988; 148: 626-631
[45] Siebers M], Drinka P], Vergauwen C. Hyperthyroidism as a cause of atrial fibrillation in long-term care. Arch Intern Med 1992; 152: 2063-2064

[46] Kirchhof P, Benussi S, Kotecha D, Ahlsson A, Atar D, Casadei B, Castella M, Diener HC, Heidbuchel H, Hendriks J, Hindricks G, Manolis AS, Oldgren J, Popescu BA, Schotten U, Van Putte B, Vardas P, Agewall S, Camm J, Baron Esquivias G, Budts W, Carerj S, Casselman F, Coca A, De Caterina R, Deftereos S, Dobrev D, Ferro JM, Filippatos G, Fitzsimons D, Gorenek B, Guenoun M, Hohnloser SH, Kolh P, Lip GY, Manolis A, McMurray J, Ponikowski P, Rosenhek R, Ruschitzka F, Savelieva I, Sharma S, Suwalski P, Tamargo JL, Taylor C], Van Gelder IC, Voors AA, Windecker S, Zamorano JL, Zeppenfeld K. 2016 ESC Guidelines for the management of atrial fibrillation developed in collaboration with EACTS. Eur Heart J 2016; 37: 2893-2962

[47] Sawin CT, Geller A, Wolf PA, Belanger A], Baker E, Bacharach P, Wilson PW, Benjamin EJ, D'Agostino RB. Low serum thyrotropin concentrations as a risk factor for atrial fibrillation in older persons. N Engl J Med 1994; 331: 1249-1252

[48] Auer J, Scheibner P, Mische T, Langsteger W, Eber O, Eber B. Subclinical hyperthyroidism as a risk factor for atrial fibrillation. Am Heart J 2001; 142: $838-842$

[49] Gammage MD, Parle JV, Holder RL, Roberts LM, Hobbs FD, Wilson S, Sheppard MC, Franklyn JA. Association between serum free thyroxine concentration and atrial fibrillation. Arch Intern Med 2007; 167: 928-934

[50] Heeringa J, Hoogendoorn EH, van der Deure WM, Hofman A, Peeters RP, Hop WC, den Heijer M, Visser TJ, Witteman JC. High-normal thyroid function and risk of atrial fibrillation: The Rotterdam study. Arch Intern Med 2008; 168: 2219-2224

[51] Vadiveloo T, Donnan PT, Cochrane L, Leese GP. The Thyroid Epidemiology, Audit, and Research Study (TEARS): Morbidity in patients with endogenous subclinical hyperthyroidism. J Clin Endocrinol Metab 2011; 96: 1344-1351

[52] Sgarbi JA, Villaca FG, Garbeline B, Villar HE, Romaldini JH. The effects of early antithyroid therapy for endogenous subclinical hyperthyroidism in clinical and heart abnormalities. J Clin Endocrinol Metab 2003; 88: 1672-1677

[53] Biondi B, Fazio S, Palmieri EA, Tremalaterra R, Angellotti G, Bone F, Riccio G, Cittadini A, Lombardi G, Sacca L. Effects of chronic subclinical hyperthyroidism from levothyroxine on cardiac morphology and function. Cardiologia 1999; 44: 443-449

[54] Gen R, Akbay E, Camsari A, Ozcan T. P-wave dispersion in endogenous and exogenous subclinical hyperthyroidism. J Endocrinol Invest 2010; 33: $88-91$

[55] Cetinarslan B, Akkoyun M, Canturk Z, Tarkun I, Kahranman G, Komsuoglu B. Duration of the $\mathrm{P}$ wave and $\mathrm{P}$ wave dispersion in subclinical hyperthyroidism. Endocr Pract 2003; 9: 200-203

[56] Aras D, Maden O, Ozdemir O, Aras S, Topaloglu S, Yetkin E, Demir AD, Soylu MO, Erdogan MF, Kisacik HL, Korkmaz S. Simple electrocardiographic markers for the prediction of paroxysmal atrial fibrillation in hyperthyroidism. Int J Cardiol 2005; 99: 59-64

[57] Mittelmeier $\mathrm{H}$, Heisel J. Sixteen-years' experience with ceramic hip prostheses. Clin Orthop Relat Res 1992; 64-72

[58] Biondi B, Fazio S, Carella C, Amato G, Cittadini A, Lupoli G, Sacca L, Bellastella A, Lombardi G. Cardiac effects of long term thyrotropin-suppressive therapy with levothyroxine. J Clin Endocrinol Metab 1993; 77: 334-338

[59] Rosario PW, Carvalho M, Calsolari MR. Symptoms of thyrotoxicosis, bone metabolism and occult atrial fibrillation in older women with mild endogenous subclinical hyperthyroidism. Clin Endocrinol (Oxf) 2016; 85: 132-136

[60] Freedberg AS, Papp JG, Williams EM. The effect of altered thyroid state on atrial intracellular potentials. J Physiol 1970; 207: 357-369 
[61] Mancia G, Fagard R, Narkiewicz K, Redon J, Zanchetti A, Bohm M, Christiaens T, Cifkova R, De Backer G, Dominiczak A, Galderisi M, Grobbee DE, Jaarsma T, Kirchhof P, Kjeldsen SE, Laurent S, Manolis AJ, Nilsson PM, Ruilope LM, Schmieder RE, Sirnes PA, Sleight P, Viigimaa M, Waeber B, Zannad F, Redon J, Dominiczak A, Narkiewicz K, Nilsson PM, Burnier M, Viigimaa M, Ambrosioni E, Caufield M, Coca A, Olsen MH, Schmieder RE, Tsioufis C, van de Borne P, Zamorano JL, Achenbach S, Baumgartner H, Bax J], Bueno H, Dean V, Deaton C, Erol C, Fagard R, Ferrari R, Hasdai D, Hoes AW, Kirchhof P, Knuuti J, Kolh P, Lancellotti P, Linhart A, Nihoyannopoulos P, Piepoli MF, Ponikowski P, Sirnes PA, Tamargo JL, Tendera M, Torbicki A, Wijns W, Windecker S, Clement DL, Coca A, Gillebert TC, Tendera M, Rosei EA, Ambrosioni E, Anker SD, Bauersachs J, Hitij JB, Caulfield M, De Buyzere M, De Geest S, Derumeaux GA, Erdine S, Farsang C, Funck-Brentano C, Gerc V, Germano G, Gielen S, Haller H, Hoes AW, Jordan J, Kahan T, Komajda M, Lovic D, Mahrholdt H, Olsen MH, Ostergren J, Parati G, Perk J, Polonia J, Popescu BA, Reiner Z, Ryden L, Sirenko Y, Stanton A, Struijker-Boudier H, Tsioufis C, van de Borne P, Vlachopoulos C, Volpe M, Wood DA. 2013 ESH/ESC guidelines for the management of arterial hypertension: The Task Force for the Management of Arterial Hypertension of the European Society of Hypertension (ESH) and of the European Society of Cardiology (ESC). Eur Heart J 2013; 34: 2159-2219

[62] Walsh JP, Bremner AP, Bulsara MK, O'Leary P, Leedman PJ, Feddema P, Michelangeli V. Subclinical thyroid dysfunction and blood pressure: A community-based study. Clin Endocrinol (Oxf) 2006; 65: 486-491

[63] Kaminski G, Makowski K, Michalkiewicz D, Kowal J, Ruchala M, Szczepanek E, Gielerak G. The influence of subclinical hyperthyroidism on blood pressure, heart rate variability, and prevalence of arrhythmias. Thyroid 2012; 22: 454-460

[64] Volzke H, Alte D, Dorr M, Wallaschofski H, John U, Felix SB, Rettig R. The association between subclinical hyperthyroidism and blood pressure in a population-based study. J Hypertens 2006; 24: 1947-1953

[65] Volzke H, Ittermann T, Schmidt CO, Dorr M, John U, Wallaschofski H, Stricker BH, Felix SB, Rettig R. Subclinical hyperthyroidism and blood pressure in a population-based prospective cohort study. Eur J Endocrinol 2009; 161: 615-621

[66] Biondi B, Palmieri EA, Fazio S, Cosco C, Nocera M, Sacca L, Filetti S, Lombardi G, Perticone F. Endogenous subclinical hyperthyroidism affects quality of life and cardiac morphology and function in young and middle-aged patients. J Clin Endocrinol Metab 2000; 85: 4701-4705

[67] Petretta M, Bonaduce D, Spinelli L, Vicario ML, Nuzzo V, Marciano F, Camuso P, De Sanctis V, Lupoli G. Cardiovascular haemodynamics and cardiac autonomic control in patients with subclinical and overt hyperthyroidism. Eur J Endocrinol 2001; 145: 691-696

[68] Casu M, Cappi C, Patrone V, Repetto E, Giusti M, Minuto F, Murialdo G. Sympatho-vagal control of heart rate variability in patients treated with suppressive doses of L-thyroxine for thyroid cancer. Eur J Endocrinol 2005; 152: 819-824

[69] Faber J, Wiinberg N, Schifter S, Mehlsen J. Haemodynamic changes following treatment of subclinical and overt hyperthyroidism. Eur J Endocrinol 2001; 145: 391-396

[70] Bengtsson D, Brudin L, Wanby P, Carlsson M. Previously unknown thyroid dysfunction in patients with acute ischemic stroke. Acta Neurol Scand 2012; 126: 98-102

[71] Cappola AR, Fried LP, Arnold AM, Danese MD, Kuller LH, Burke GL, Tracy RP, Ladenson PW. Thyroid status, cardiovascular risk, and mortality in older adults. JAMA 2006; 295: 1033-1041
[72] Collet TH, Gussekloo J, Bauer DC, den Elzen WP, Cappola AR, Balmer P, lervasi G, Asvold BO, Sgarbi JA, Volzke H, Gencer B, Maciel RM, Molinaro S, Bremner A, Luben RN, Maisonneuve P, Cornuz J, Newman $A B$, Khaw KT, Westendorp RG, Franklyn JA, Vittinghoff E, Walsh JP, Rodondi N.Thyroid Studies C. Subclinical hyperthyroidism and the risk of coronary heart disease and mortality. Arch Intern Med 2012; 172: 799-809

[73] Drechsler C, Schneider A, Gutjahr-Lengsfeld L, Kroiss M, Carrero J], Krane V, Allolio B, Wanner C, Fassnacht M. Thyroid function, cardiovascular events, and mortality in diabetic hemodialysis patients. Am J Kidney Dis 2014; 63: 988-996

[74] Schultz M, Kistorp C, Raymond I, Dimsits J, Tuxen C, Hildebrandt P, Faber J. Cardiovascular events in thyroid disease: A population based, prospective study. Horm Metab Res 2011; 43: 653-659

[75] Selmer C, Olesen JB, Hansen ML, von Kappelgaard LM, Madsen JC, Hansen PR, Pedersen OD, Faber J, Torp-Pedersen C, Gislason GH. Subclinical and overt thyroid dysfunction and risk of all-cause mortality and cardiovascular events: A large population study. J Clin Endocrinol Metab 2014; 99: 2372-2382

[76] Wollenweber FA, Zietemann V, Gschwendtner A, Opherk C, Dichgans $M$. Subclinical hyperthyroidism is a risk factor for poor functional outcome after ischemic stroke. Stroke 2013; 44: 1446-1448

[77] Ahmed A. American College of Cardiology/American Heart Association Chronic Heart Failure Evaluation and Management guidelines: Relevance to the geriatric practice. J Am Geriatr Soc 2003; 51: 123-126

[78] Ponikowski P, Voors AA, Anker SD, Bueno H, Cleland JG, Coats AJ, Falk V, Gonzalez-Juanatey JR, Harjola VP, Jankowska EA, Jessup M, Linde C, Nihoyannopoulos P, Parissis JT, Pieske B, Riley JP, Rosano GM, Ruilope LM, Ruschitzka F, Rutten FH, van der Meer P.Authors/Task Force M. 2016 ESC Guidelines for the diagnosis and treatment of acute and chronic heart failure: The Task Force for the diagnosis and treatment of acute and chronic heart failure of the European Society of Cardiology (ESC)Developed with the special contribution of the Heart Failure Association (HFA) of the ESC. Eur Heart J 2016; 37: 2129-2200

[79] Wang W, Guan H, Gerdes AM, lervasi G, Yang Y, Tang YD. Thyroid Status, Cardiac Function, and Mortality in Patients With Idiopathic Dilated Cardiomyopathy. J Clin Endocrinol Metab 2015; 100: 3210-3218

[80] Nanchen D, Gussekloo J, Westendorp RG, Stott DJ, Jukema JW, Trompet S, Ford I, Welsh P, Sattar N, Macfarlane PW, Mooijaart SP, Rodondi N, de Craen AJ.Group P. Subclinical thyroid dysfunction and the risk of heart failure in older persons at high cardiovascular risk. J Clin Endocrinol Metab 2012; 97: 852-861

[81] Gencer B, Collet TH, Virgini V, Bauer DC, Gussekloo J, Cappola AR, Nanchen D, den Elzen WP, Balmer P, Luben RN, lacoviello M, Triggiani V, Cornuz J, Newman AB, Khaw KT, Jukema JW, Westendorp RG, Vittinghoff E, Aujesky D, Rodondi N.Thyroid Studies C. Subclinical thyroid dysfunction and the risk of heart failure events: An individual participant data analysis from 6 prospective cohorts. Circulation 2012; 126: $1040-1049$

[82] Rodondi N, Bauer DC, Cappola AR, Cornuz ], Robbins ], Fried LP, Ladenson PW, Vittinghoff E, Gottdiener JS, Newman AB. Subclinical thyroid dysfunction, cardiac function, and the risk of heart failure. The Cardiovascular Health study. J Am Coll Cardiol 2008; 52: 1152-1159

[83] Asvold BO, Bjoro T, Platou C, Vatten L]. Thyroid function and the risk of coronary heart disease: 12-year follow-up of the HUNT study in Norway. Clin Endocrinol (Oxf) 2012; 77: 911-917

[84] Parle JV, Maisonneuve P, Sheppard MC, Boyle P, Franklyn JA. Prediction of all-cause and cardiovascular mortality in elderly people from one low serum thyrotropin result: A 10-year cohort study. Lancet 2001; 358: 861-865 
[85] Haentjens P, Van Meerhaeghe A, Poppe K, Velkeniers B. Subclinical thyroid dysfunction and mortality: An estimate of relative and absolute excess all-cause mortality based on time-to-event data from cohort studies. Eur J Endocrinol 2008; 159: 329-341

[86] Ochs N, Auer R, Bauer DC, Nanchen D, Gussekloo J, Cornuz J, Rodondi N. Meta-analysis: subclinical thyroid dysfunction and the risk for coronary heart disease and mortality. Ann Intern Med 2008; 148: 832-845

[87] Volzke H, Schwahn C, Wallaschofski H, Dorr M. Review: The association of thyroid dysfunction with all-cause and circulatory mortality: Is there a causal relationship? J Clin Endocrinol Metab 2007; 92: 2421-2429

[88] Singh S, Duggal J, Molnar J, Maldonado F, Barsano CP, Arora R. Impact of subclinical thyroid disorders on coronary heart disease, cardiovascular and all-cause mortality: a meta-analysis. Int J Cardiol 2008; 125: 41-48

[89] Surks MI, Ortiz E, Daniels GH, Sawin CT, Col NF, Cobin RH, Franklyn JA, Hershman JM, Burman KD, Denke MA, Gorman C, Cooper RS, Weissman NJ. Subclinical thyroid disease: scientific review and guidelines for diagnosis and management. JAMA 2004; 291: 228-238

[90] Selmer C, Olesen JB, Hansen ML, Lindhardsen J, Olsen AM, Madsen JC, Faber J, Hansen PR, Pedersen OD, Torp-Pedersen C, Gislason GH. The spectrum of thyroid disease and risk of new onset atrial fibrillation: a large population cohort study. BMJ 2012; 345: e7895
[91] Goichot B, Caron P, Landron F, Bouee S. Clinical presentation of hyperthyroidism in a large representative sample of outpatients in France: relationships with age, aetiology and hormonal parameters. Clin Endocrinol (Oxf) 2016; 84: 445-451

[92] Poola R, Mathiason MA, Caplan RH. A retrospective study of the natural history of endogenous subclinical hyperthyroidism. WMJ 2011; 110: $277-280$

[93] Duarte GC, Tomimori EK, Camargo RY, Rubio IG, Wajngarten M, Rodrigues AG, Knobel M, Medeiros-Neto G. The prevalence of thyroid dysfunction in elderly cardiology patients with mild excessive iodine intake in the urban area of Sao Paulo. Clinics (Sao Paulo) 2009; 64: 135-142

[94] Klein Hesselink EN, Lefrandt JD, Schuurmans EP, Burgerhof JG, Groen B, Gansevoort RT, van der Horst-Schrivers AN, Dullaart RP, Van Gelder IC, Brouwers AH, Rienstra M, Links TP. Increased risk of atrial fibrillation after treatment for differentiated thyroid carcinoma. J Clin Endocrinol Metab 2015; 100: 4563-4569 